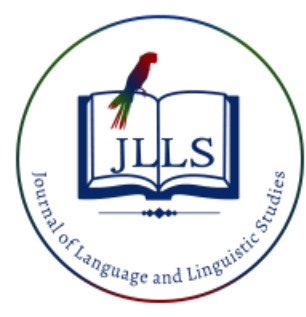

Available online at www.jlls.org

JOURNAL OF LANGUAGE AND LINGUISTIC STUDIES

ISSN: 1305-578X

Journal of Language and Linguistic Studies, 17(1), 398-411; 2021

\title{
Use of persuasion and newspapers' representations of conflicts
}

\author{
Naeem Afzal a ${ }^{\text {iD }}$, Ismat Jabeen ${ }^{\text {b }}$ iD, Ansa Hameed ${ }^{\text {iD }}$, Adnan Rashid Sheikh ${ }^{\text {d }}$ iD \\ ${ }^{a}$ Prince Sattam bin Abdulaziz University, Al-Kharj, Saudi Arabia \\ ${ }^{b}$ Prince Sattam bin Abdulaziz University, Al-Kharj, Saudi Arabia \\ cPrince Sattam bin Abdulaziz University, Al-Kharj, Saudi Arabia \\ ${ }^{d}$ Umm Al Qura University, Makkah Mukarrama, Saudi Arabia
}

\section{APA Citation:}

Afzal, N., Jabeen, I., Hameed, A., \& Sheikh, A.R., (2021). Use of persuasion and newspapers' representations of conflicts. Journal of Language and Linguistic Studies, 17(1), 398-411. Doi: 10.52462/j1ls.24

Submission Date: 09/01/2021

Acceptance Date: 13/03/2021

\begin{abstract}
Persuasion in media discourses produces certain meanings and mobilizes public attitudes in a set direction. Logical appeals, for instance, are created to gather public support for a particular viewpoint, which propagates a specific cause. This paper critically investigates the newspaper's use of persuasion strategies employed by editorial writers to represent the 2011 Arab Spring conflict. The data consist of 20 newspaper editorials published in the Arab News (AN) belonging to the Arab region yet presumed as a newspaper's voice from a nonArab spring country. The purpose is to probe journalistic roles and discursive positions taken in representing the conflict. The content analysis technique is used to examine the selected editorials. Findings reveal that the newspaper (AN) constructed the events persuasively and portrayed different aspects of the uprising. This study points out that editorial writers relied on several logical appeals to, almost, set a pro-Arab Spring stage. In addition, it has been noticed that the AN adopted a more compassionate attitude towards protesters' losses, and their ambitions for bringing a 'change' were justified, generally, than the ruling authorities. Overall, the findings reaffirm the media's contribution to represent conflicts in different societies under social, cultural, political, and national parameters by using certain tools of persuasion. This study recommends that future research should draw a comparison between news reports and editorial opinions, and investigate post-Arab Spring situations.
\end{abstract}

Keywords: Persuasion; logical appeals; Arab Spring conflict; media discourse; newspaper editorials

\section{Introduction}

Mass media frame the understanding or misunderstanding of people and communities, construct their image, and act as an agent to (re) shape their perceptions (Alshahrani, 2021). By using the language neatly, mass media transfer information to readers in a way that shapes the concept of understanding (Triana, Kustati, Yusuf, \& Reflinaldi, 2021). Media has emerged as a weapon to mobilize millions in the contemporary global age mainly through linguistic means. Language is operated persuasively in all forms of media. However, to understand the use of persuasion, there is a need to outline techniques such as identifying the central message, that convinces readers to accept the writer's viewpoint, and emotive language, which triggers readers' feelings. The purpose of all such

\footnotetext{
${ }^{1}$ Corresponding author.

E-mail address: n.awan@psau.edu.sa
} 
different writing maneuvers is to impose a particular effect on readers by using persuasive language, evidence, and arguments to manipulate audiences' responses, target their emotions, and their use of logic and reason (Breuer, Napthine \& O'Shea, 2008). Figure 1 illustrates some of the factors considered significant in media representations.

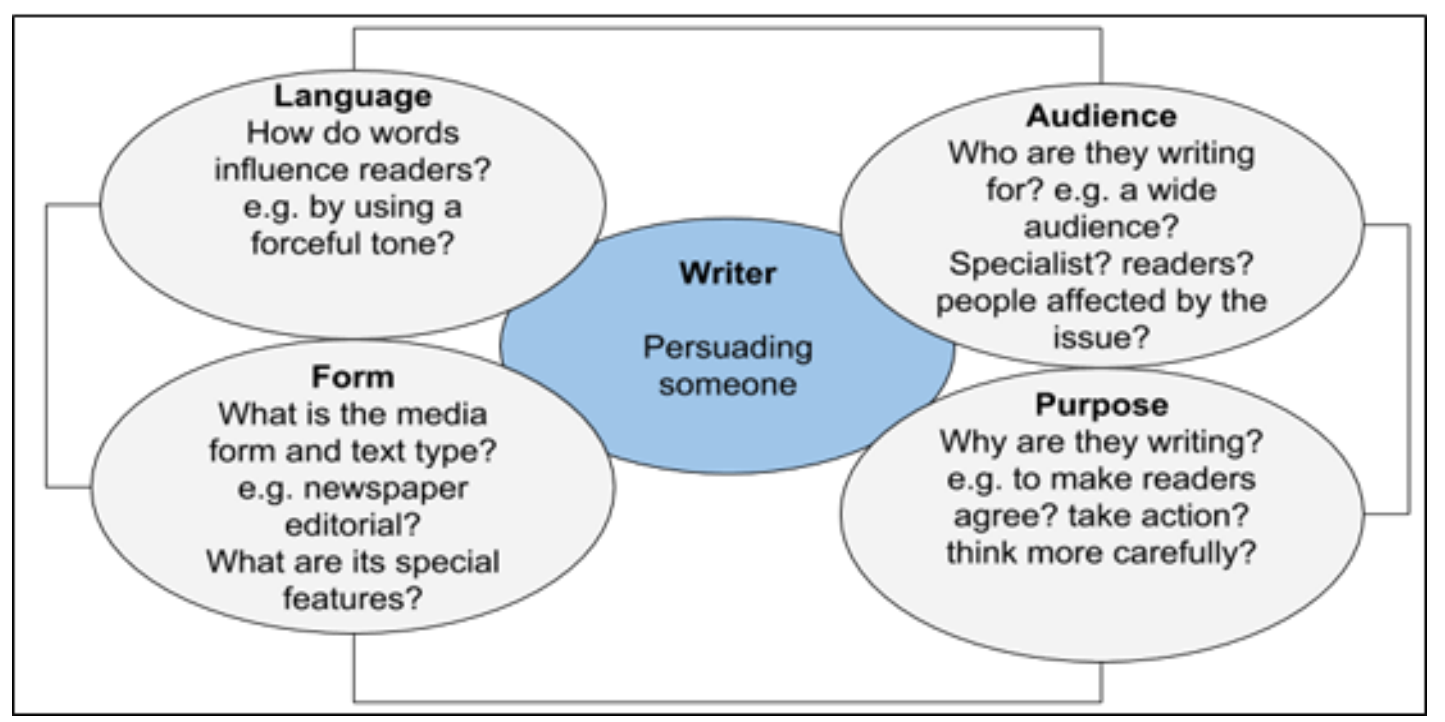

Figure 1. Factor considered in media representations (Source: Adapted from Breuer, Napthine, and O'Shea (2008)

How newspapers represent the Arab Spring conflict by using persuasion strategies is the concern of the present study. The uprising in Tunisia, Yemen, Egypt, Libya, and Syria, became observable on a major scale because it intended to bring reformation and toppled decades-old regimes (Martin, 2014). At the outset, the Arab Spring was imagined as an "inspirational movement" by those who favored the protests and demanded a new-style Arab society with better ways of living and governance (Culbertson, 2016). It was also planned to create a new epoch in the history of protesting nations (Kadri, 2016). Thus, due to such significant implications, the uprising attracted numerous research scholars from different domains including media research scholars (Asmeret, 2013). A majority of past research on the Arab Spring (e.g., Barnsby, 2012; Creech, 2014; Hassan, 2015; Kamel, 2014; Lynch, Freelon \& Aday, 2014; Skinner, 2011) examined social media coverage of events. Studies conducted on newspaper coverage of the Arab Spring (e.g., AlMaskati, 2012; Amin \& Jalilifar, 2013; Bardici, 2012; Dağtaş, 2013; Eskjær, 2012; Hamdy \& Gomaa, 2012), hardly focussed on the use of persuasion appeals. This study intends to investigate:

1- Persuasion strategies used by editorial writers of the AN to mirror the Arab Spring conflicts.

2- The newspaper's agenda for using persuasion strategies.

Inline, the research questions were the following:

1- How did the editorial writers of the AN use persuasion strategies to mirror Arab Spring?

2- What was the newspaper's agenda for the usage of particular persuasion strategies?

This study adopts the content analysis approach to analyze the Arab Spring editorials selected through certain keywords (see Table 1). It intends to gain insights into how the conflicts were mirrored by newspaper editorial writers who have the power and means to (re)shape readers' decision-making. 


\section{Theoretical Framework}

Rhetorical constructions in discourses disseminate views about globalization, legitimize specific strategies regarding social agents or agencies, justify policies, and rationalize certain actions (Fairclough, 2006). It is not surprising to expect that rhetorical constructions contribute to manipulating ideologies and rhetoric delivers persuasive communication by managing how audiences evaluate and understand events (van Dijk, 1998). Rhetoric refers to the "faculty of observing in any given case the available means of persuasion" (Aristotle, 1356/2006, p. 7). Thus, Aristotle means rhetoric yields persuasion and texts that have a theoretical element in them. The theoretical framework of this study relies on Aristotle's concept of three appeals or means of persuasion (ethos, pathos, and logos) often used to construct a framework for analyzing arguments (Lamberti, 2013). The three modes of persuasion are also recognized as three types of proofs described as ethical proof (ethos), emotional proof (pathos), and logical proof (logos) as suggested by Steinberg (1999). This study relies on the third mode/appeal of persuasion logos to investigate the editorial representations of the Arab Spring. To, briefly elaborate, Logos is finished through persuasive arguments by using "the proof or apparent proof" (Aristotle, 1356/2006, p. 4). In Aristotle's words, it is a "persuasive tactic that employed the arguments or reasons for actions that the populace deemed most logical" (Larson, 1992, p. 54). Since through logos the writer persuades the audience by relying on logical and rational arguments, at times, this persuasive appeal overcomes other appeals of persuasion (Halmari \& Virtanen, 2005; Shabo, 2010; White, 2006). Logos, logical appeal, has been considered a common means of building arguments and providing factual information that supports an individual's position on a particular issue (English, Sweetser, \& Ancu, 2011). Logos promotes the integrity and clarity of arguments by stressing logic and appeals to reason. In rhetoric, logos refer to the appearance of rationality rather than just reality (Higgins \& Walker, 2012). As a rhetorical appeal, logos constitutes and binds together arguments that should be presented by authors in a logical sequence. However, the intelligibility of logos also depends on the audiences' ability to following the author's line of reasoning (Varpio, 2018). Based on Aristotle's concept of logos (logical appeals), this study reveals the persuasive use of language by the AN editorial writers in mirroring the Arab Spring conflict.

\section{Literature Review}

Research studies on Arab Spring are generally categorized into two types: social media studies and news media studies. A bulk of studies on Arab Spring witness examined social media coverage of the uprising. To cite, some of the studies focused on the Facebook posts and Tweets related to the Arab Spring events (e.g., Aouragh 2012; Barnsby, 2012; Creech, 2014; Schueller, 2012; Skinner, 2011). Other studies examined Tweets shared about the Arab Spring (e.g., Bruns, Highfield \& Burgress, 2013; Lotan, et al., 2011; Lynch, Freelon \& Aday, 2014; Starbird \& Palen, 2012). The research studies also investigated the coverage of the Arab Spring by YouTube, Twitter, Facebook, online bloggers, and mobile telephony (e.g., Cottle, 2011). Furthermore, there have been studies that probed how Facebook, Twitter, and blogs (e.g., Eltantawy \& Wiest, 2011) represented the events. More studies were conducted on the uprising coverage by Facebook, Twitter, and YouTube (Chebib \& Sohail, 2011; Hassan, 2015), Twitter, Facebook, blogs, YouTube (e.g., Kamel, 2014), the Internet (e.g., Chokoshvili, 2011), and Facebook (e.g., Tufekci \& Wilson, 2012). Hence, it is argued that researchers in the past gave more preference to social media coverage and comparatively less attention was paid to newspaper coverage of the events.

The review of contemporary news media studies reflects that researchers neglected the newspaper use of persuasion, editorials in particular, in portraying the Arab Spring. To cite a few, Alhumaidi (2013) investigated how Al-Ahram, Egypt's government-owned newspaper and, Aljazeera, a Qatar- 
based news network represented the conflict. This study reported that the conflicts were portrayed under 'group polarization, in-group and out-group representations. Baum and Zhukov (2015) investigated newspaper articles, from 113 countries. It examined media tendency of under-reporting or over-reporting events that depended on the political orientation of a new organization. Abushouk (2014) examined the causes of the Arab Spring and their consequence published by the Time and Newsweek (American) magazines in 2011. It was revealed that political dictatorship, corruption, youthquake in the Arab world, and use of cell phones and social media were root causes of the uprising in Tunisia, Egypt, Libya, and Yemen. Youssef (2012) investigated the newspaper representations of the Egyptian uprising in Al-Ahram and Al-Masry Al-Youm (Egypt), The Telegraph (Britain), and The Washington Post (America). This study focused on the media use of 'positive selfpresentation' and 'negative other presentation. The study by Alasuutari, Qadir, and Creutz (2013) analyzed online news stories, articles, editorials, and letters to the editor published in British (The Times), Finnish (Helsingin Sanomat), and Pakistani (Daily Times) newspapers representing the Egyptian uprising. It was reported that several discursive strategies were used to domesticate events such as appeals to emotions. More studies were also conducted on newspaper coverage of the Arab Spring (e.g., AlMaskati, 2012; Amin \& Jalilifar, 2013; Bardici, 2012; Dağtaş, 2013; Eskjær, 2012; Hamdy \& Gomaa, 2012). Hence, it is argued that researchers hardly focused on persuasion strategies used by newspaper editorials in representing the conflict. The present research investigates the use of 'logos' as a mode of persuasion employed by the AN.

\section{Methodology}

To investigate the newspaper's use of persuasion appeals to logos, 20 editorials were selected from the Arab News of Saudi Arabia - supposedly representing a vivid assessment of the situation due to cultural and regional proximity with the uprising nations. The data consist of editorials published between January 2011 and December 2012. To ensure that the Arab Spring remained the central topic of editorials, Concordance was used to sort keywords (see Table 1).

Table 1. Keywords representing the Arab Spring

\begin{tabular}{ll}
\hline Keywords & Recurrence in Numbers \\
\hline Arab & 75 \\
Assad & 47 \\
Qaddafi & 41 \\
Egypt & 39 \\
Libya & 39 \\
Syria & 35 \\
Syrian & 30 \\
Arab League & 30 \\
Forces & 28 \\
Tunisia & 21 \\
Mubarak & 20 \\
Protesters & 20 \\
Libyan & 18
\end{tabular}




\begin{tabular}{ll} 
Revolution & 14 \\
Arab Spring & 10 \\
Killing & 10 \\
Uprising & 9 \\
Protests & 8 \\
Zine El-Abedine Ben Ali & 6 \\
Ali Abdullah Saleh & 6 \\
Riots & 5 \\
\hline
\end{tabular}

Through qualitative content analysis, the data were read and re-read to make sense of the editorial descriptions and understand the intended message. However, it is essential to focus on certain textual components that reflect the argumentation and system of reasoning (Higgins \& Walker, 2012). Table 2 demonstrates some of the linguistic indicators (Ting, 2018) used to investigate appeals to logos.

Table 2. Framework for analyzing persuasive appeals (logos) in newspaper editorials

\begin{tabular}{|c|c|c|}
\hline Means of Persuasion & Appeal to & Strategies/Techniques \\
\hline \multirow{20}{*}{ Logos } & \multirow{20}{*}{$\begin{array}{l}\text { Logic, rationality, } \\
\text { reason }\end{array}$} & Argumentation \\
\hline & & Logic \\
\hline & & Warrants/justification \\
\hline & & Claims \\
\hline & & Data \\
\hline & & Evidence/Examples \\
\hline & & Factual language \\
\hline & & Questioning and wondering \\
\hline & & Linguistic links: initially, later and finally ${ }^{1}$ \\
\hline & & Appeal to the mind/intellect \\
\hline & & Draw from philosophy and logic \\
\hline & & Facts \\
\hline & & Statistics \\
\hline & & If, then... statements \\
\hline & & Definitions of terms \\
\hline & & Explanation of ideas \\
\hline & & Cause and effect \\
\hline & & Details that come from objective reporting \\
\hline & & Logical reasons and explanations \\
\hline & & Counterargument and rebuttal ${ }^{2}$. \\
\hline
\end{tabular}




\section{Results}

The analysis of the editorials revealed that the AN used several logical appeals to deliver its stance on the Arab uprising.

[Editorial Comment] Tunisia needs stable transition...need is to ban anyone connected to the old regime. Iraq has shown the deadly folly of that .....(AN, January 19, 2011)

The above logos-centric opinion emphasized a stable transition in Tunisia. As an outcome of the Arab Spring, the old regime in the country was dethroned by the 2011 protests that demanded change and sought dismissal of the existing regime. By exemplifying and historically referring to Iraq's situation, the editorial rejected interventions of old regime party/members into new administrative setup. The AN persuaded readers to probably trust the protesters' aspiration for change and desire to constitute a new government.

[Editorial Comment] It should have been one of the richest nations on earth. He has wasted much of its oil wealth exporting his dreams of revolution far and wide. (AN, February 22, 2011)

The comment portrayed the situation in Libya. The AN blamed the Libyan leader for wasting oil wealth that caused poverty in the country and ultimately protesters revolted against the regime. The logos-based opinion further claimed that Qaddafi misused the country's resources just for transferring his own dreams of revolutions worldwide. Such persuasively charged comments meant to expose the reasons behind the Libyan uprising and provide an underlying justification for the change.

[Editorial Comment] The people have taken control of their own affairs. Libyans want to do the same...butchered for their efforts. The responsibility ... fellow Arabs...must not be avoided or betrayed. A new Arab world ... were freedom ... (AN, February 25, 2011)

This justification positively portrayed protesters' actions in Tunisia and Egypt. It was claimed that Libyans were butchered for taking control of their own affairs in the country. The newspaper argued that it was the responsibility of fellow Arab countries to save Libyans from the regime's anti-change actions and must not betray Libyans. The comment implied that people in the Arab Spring countries had little or no freedom in the pre-Arab Spring era. However, it was predicted that a new Arab world was being born that would bring more freedom after the departure of old regimes. Such unequivocal appeals represented Libyans' desire for change.

[Editorial Comment] The longer Qaddafi is allowed...the Arab-African country...will suffer...helpless ... simply means the loss of hundreds, perhaps thousands, of more innocent lives...the blaze...its flames.... (AN, February 28, 2011)

Another editorial warrant advocated the exit of Qaddafi as demanded by protesters. It was warned that if the Libyan leader continued the county would suffer. The logos-based argument metaphorically represented the Libyan uprising as ablaze and cautioned that it could spread beyond Libyan borders and surround the whole region. The situation was described as helpless and wasteful by claiming that innocent people were losing still their lives and no concrete action was taken at the international level to save them. Such an editorial opinion echoes newspaper's concern about Arab Spring protesters and their ill-treatment by the Libyan authorities.

[Editorial Comment] There will not be peace while he remains. But were he to go and not be replaced by a strong central government in Sanaa, it would be a disaster-for Yemen...for the region. That cannot be ignored... (AN, March 25, 2011)

The AN constructed several logical appeals to defend the Arab Spring protesters. In the case of the uprising in Yemen, the above editorial argument rationalized that the stay of the Yemeni President in power would aggravate the situation because the protesters were removing the removal of authorities 
as they did in other countries. The unpredictable situation in the country was portrayed as a disaster and a security threat for the whole region through lexical choice as cannot be ignored. So, to the AN uprising never meant just throwing out the old regime but it also expressed concerns over postuprising scenarios such as stable transitions and administrative setups arranged locally without outside interferences.

[Editorial Comment] The Arab League did not suspend Syria's membership, did not call on Assad to step aside ... avoiding seeing another Arab leader toppled violently and dragged through the streets, as was the fate of Libyan leader ... (AN, April 12, 2011).

This logo-based appeal represented the Syrian situation where the Arab Spring protesters demanded the exit of President Assad, portrayed as defiant against the protesters who did not respect deals and refused to step down by accepting their demands. Reportedly, Syrian security forces were killing demonstrators with violent crackdowns on them. Despite such developments, the AN reasoned that the Arab League, which was playing its role to normalize the situation, did not suspend Syria's membership perhaps due to its apprehensions that the Syrian President might face the same fate that was faced by Qaddafi - removed and dragged through the streets.

[Editorial Comment] As the intellectual and cultural leader of the Arab world, what happens in Egypt will have far-reaching ramifications for the entire region that is right now undergoing cataclysmic changes. (AN, April 15, 2011)

By representing the situation in Egypt, the editorial logos predicted that the uprising in Egypt would have its consequences far beyond the region. This editorial claim was based on the logic that Egypt was not a simple country; it was rather portrayed as the intellectual and cultural leader of the world. The editorial comment magnified the importance of the country in the Arab world and an impression has created the case of Egypt would set an example for others.

[Editorial Comment] Even so, few world leaders...trial...makes the Mubarak case so significant...his trial is immensely important as well as symbolic ... reason for suspecting that the Egyptian revolution is as yet an unfinished affair. (AN, August 04, 2011)

Apparently, the AN accepted that President Mubarak's trial in Egypt was significant by giving several reasons. Firstly, few world leaders were brought to such a trial. Secondly, it was enormously symbolic because he was at the apex of power. However, it was logically emphasized that Mubarak was not the only person that should be charged but they were others as well. The logos reasoned that this development of blames on one person created suspicion and made the Egyptian revolution an unfinished affair.

[Editorial Comment] Inevitably ... fears about what happens next. Who will take over? Will proQaddafi forces sabotage peace ...? Will the victors fall out among themselves? Will there be a spate of revenge killings? Will the shadow of militancy fall across the country as happened in Iraq ...? (AN, August 04, 2011)

Such rhetorical questions predicted the post-Qaddafi scenario in Libya. This rhetorically loaded argument reasoned several fears that could damage post-uprising transitions. The first apprehension was as to who would make the new government amid the existence of several armed groups. The second type of fear was that pro-Qaddafi forces might sabotage the peace process. Third, a judgment was also given that victors of the Arab Spring might have conflicts for certain reasons. A revengeful series of killings by different armed groups was claimed as another type of fear that could harm the peace process. Lastly, another rhetorical question warned militancy might prevail in the post-Arab Spring situation; the case of Iraq was given as proof. 
[Editorial Comment] However, whether it is Ali Abdullah Saleh of Yemen or his counterpart in Damascus, they have to wake up to the reality that change has come to the Middle East. The age of endless and absolute power is over. (AN, October 19, 2011)

Another editorial assertion comparatively reviewed the situation in Yemen and Syria. The newspaper warned the authorities of the two uprising countries to realize the fact that change had come in the Middle East. The editorial argument contained an underlying endorsement of the protests launched by the Arab Spring protesters and demanded the exit of authorities in Yemen and Syria. The logical appeal referred to the change in the Middle East as reality. Based on this argument, the AN portrayed that it was time to bid farewell to old regimes. This logical appeal seemed convincing in favor of the Arab Spring.

[Editorial Comment] ... momentous year-2011 ... the Year of Arab Revolutions... the uncertainty ... the Arab Spring... in Yemen, in Syria, in Libya, and even in Tunisia and Egypt...(AN, January 20, 2012)

This logical conclusion argued that, due to the outburst of the Arab Spring, the year 2011 would be marked a historical year as demonstrated in the editorial comment above. The AN admitted the historical importance of the Arab Spring protests as one theme of the movement. Nonetheless, it also raised the point that there was uncertainty in Tunisia, Egypt, Yemen, Libya, and Syria despite political developments in the wake of the Arab Spring. Such editorial comments anticipated doubts about a successful democratic future in these countries.

[Editorial Comment] Even if the Assad regime were to survive, Moscow's standing in the Arab world is going to be deeply compromised for a long-time... compromise its relations with the rest of the Arab world, to hang on to it? (AN, March 16, 2012)

This statement was published in the AN editorial titled Russia's unfair support. It reflected the Syrian uprising and Russia's constant meddling into it despite the will of the international community. This logical explanation demonstrated that AN disapproved of Moscow's intervention in Syrian that indirectly weakened the Arab Spring momentum and strengthened the already defiant regime of Assad which constantly rejected change as aspired by the protesters. The newspaper warned that Russian relations with the Arab world would be deeply affected if it continued supporting the Assad regime. Such rationally constructed arguments echoed that AN strongly objected to outside interventions in Syrian and instead the newspaper wanted Syrians to replicate what protesters did in other countries by electing their new rulers.

[Editorial Comment] It is not just that Russia wants to hang on to her two Syrian naval bases but that both countries are exploiting ... powerlessness of the United States and the rest of the international community. (AN, March 30, 2012)

Again, commenting on the Syrian uprising, the editorial claimed that the capturing of Syrian naval bases by Russia was not the only reason for intervening in the country's affair. Instead, the AN found the reason to blame the USA and international community which did not take adequate measures to prevent Russian intervention in Syria. The lexical choice powerlessness exposed that the Assad regime and Russia both in fact exploited the indecisiveness demonstrated by superpowers to act in Syria. Hence, newspapers frequently constructed such logical appeals to stop interferences by international powers in the Arab Spring countries.

[Editorial Comment] Russia cannot behave as a responsible international citizen. It should be warned of sanctions and isolation... President Putin ... cynically defending the indefensible ... the bloody butchery that continues .. in Syria (AN, June 1, 2012) 
The newspaper's continued concern about Russia's intervention in Syria was realized in another argument as well. To end such unwanted developments, and based on editorial justification and blame, Russia cannot behave as a responsible international citizen, it was suggested that Russia should be warned of facing international isolation and sanctions. The logical appeal by claiming the Arab Spring protesters' killings in Syria rejected Putin's efforts to, cynically, defend the Assad regime that was labeled as indefensible by the AN.

\section{Discussion}

Rhetorical discourses, regardless of topics are crafted to respond to certain events and include a particular location, time, problem, and audience as well. Thus, rhetoric may involve both responsemaking and response-inviting. Persuasion is one of the goals of rhetoric. One way to accomplish such goals is to create appeals that engage the audience (Herrick, 2013). In response to the research questions of this study, it has been observed that the AN frequently employed logos, logical appeals, to construct its point of view about the Arab Spring. This study establishes that the AN editorials produced persuasively rich discourse while portraying the uprising. Often, it has been witnessed that editorials are typically written persuasively as they represent the ideological opinions of newspapers (Mureşan, 2013). Hence, newspaper editorials are regarded as a unique medium to investigate such conflicts. In most cases, it has been evidenced that the newspaper backed what was campaigned to bring changes in some Arab countries (Tunisia, Yemen, Egypt, Libya, and Syria) that faced the uprising. In the first instance, the newspaper supported protesters' demands to overthrow old regimes and elect new governments. Several lexical items from logical appeals in the AN editorials demonstrated so: taken control of their own affairs, more innocent lives, the reality that change has come, the Year of Arab Revolutions, butchered for their efforts, must not be avoided or betrayed, and so on. Editorials are a type of genre that is contextually defined concerning writers' intents and readers' expectations; they are anticipated to (re) shape opinions on contemporary news events (van Dijk, 1995).

Logos as logical appeals rely on several aspects such as reasons, facts, and premises to produce an "internal consistency" so that readers can perceive a position probably and reasonably (Hannon, 2011). The editorial logos constructed by the AN opposed the authorities, in contrast to protesters' actions, which remained to quit their regimes. Instead, they launched a severe crackdown, on the protesters, which proved bloody particularly in the case of Libya and Syria. Several logical appeals in the form of editorial blame and criticisms disapproved of the stay of authorities during anti-regime protests. To cite, the newspaper used lexical expressions such as ban anyone connected to the old regime, wasted much of its oil wealth, longer Qaddafi is allowed, not be peace while he remains, his trial is immensely important as well as symbolic, they have to wake up to the reality, bloody butchery, endless and absolute power is over, etc. These editorial judgments reveal that the newspaper negatively represented all anti-Arab Spring actions and hardly endorsed measures taken by authorities to engage the protesters. The main purpose of such appeals is to construct convincing endorsements, build up persuasiveness, and ensure that is made receptive to opinions constructed. In particular, when the newspaper is employed as a medium to deliver the message logos become "legitimating appeal" (Kamau \& Berry, 2013).

Some more logical appeals were constructed to formulate a public opinion regarding post-Arab Spring transitions. Such comments served as justifications for protesters' dream to bring dramatic changes and acknowledged their efforts. It was evidenced through lexical choices such as needs stable transition, A new Arab world, a strong central government, far-reaching ramifications, etc. Hannon (2011) also claimed that editorial writers do employ rhetorical appeals such as logos to create compelling cases for the views expressed. Despite painting an overall pro-Arab Spring picture of the 
events, the AN also made use of logic to express future uncertainties in the countries of the uprising such as flames will start scorching the whole region, it would be a disaster, undergoing cataclysmic change, an unfinished affair, fears about what happens next, the uncertainty, etc. Hence, editorial declarations presented a comprehensive picture of the uprising starting from protesters' demands, outside interventions, overthrowing of old regimes, to post-Arab Spring transitions, and future uncertainties. Haider (2016) claimed that along with other pro-revolutionary forces that motivated the pro-change elements to protest against the authorities, journalists were also seen as warriors because their writings promoted the spirit of change and revolution.

\section{Conclusion}

This study has investigated the ways editorial writers of the AN used persuasion as a tool to address and represent the Arab Spring issues. Aristotle's tenets of logical appeals (logos) provided the theoretical framework for this study. This study has attempted to give insights on how by creating such appeals to logic the newspaper positioned itself and engaged the public opinion. It has been noticed that the AN vividly portrayed the events and shared its position on all substantial aspects of the Arab Spring. The newspaper employed logos as a mode of persuasion to mostly support the Arab Spring and oppose authoritarian regimes. Overall, the editorial undertones of the newspaper implied that the authorities in the Arab Spring countries acted as anti-change elements and enraged the public that wanted to bring change. Several logical appeals demonstrated that the protesters' actions were mitigated. Their demands were logically advocated by the newspaper as it decided to adopt a defensive attitude towards the protesters vis-à-vis the authorities. This study reiterates that newspaper editorials play a decisive role by covering conflicts in a rhetorically and persuasive manner that (may) convince the audience to favor a particular side. It also reaffirms that the newspaper editorials as a dominant discourse genre invested with institutional power have presented a convening case of the Arab Spring through logical appeals. The case of the Arab Spring reflects how the mainstream media in the country were genuinely contributed to covering the events of regional and international concern. This study is limited to the Arab Spring overage by just newspaper editorials published during the uprising. It recommends that future research on the Arab Spring can be conducted from different perspectives such as by interviewing the public (protesters) involved in the Arab Spring, drawing a comparison between news reports and editorial opinions, and by investigating post-Arab situations.

\section{Acknowledgments}

The researchers would like to thank Prince Sattam bin Abdulaziz University (Deanship of Scientific Research) for their constant support, encouragement, and guidance.

\section{References}

Abushouk, A. I. (2014). Time and Newsweek's coverage of the Arab uprisings in 2011: A content analysis survey. Asian Review of World Histories, 2(1), 81-104. doi: http://dx.doi.org/10. 12773/arwh.2014.2.1.081

Alasuutari, P., Qadir, A., \& Creutz, K. (2013). The domestication of foreign news: News stories related to the 2011 Egyptian revolution in British, Finnish, and Pakistani newspapers. Media, Culture \& Society, 35(6), 692-707. doi: 10.1177/0163443713491299

Alhumaidi, M. (2013). A critical discourse analysis of Al-Ahram and Aljazeera's online coverage of Egypt's 2011 revolution (Doctoral dissertation). Available from ProQuest Dissertations and Theses database. (UMI No. 3584272) 
AlMaskati, N. A. (2012). Newspaper coverage of the 2011 protests in Egypt. International Communication Gazette, 74(4), 342-366.

Alshahrani, A. (2021). A-frame analysis of the language used by eight US media to describe the role of China and Chinese in spreading Covid-19 from late January to early June 2020. Journal of Language and Linguistic Studies, 17(Special Issue 2), 1129-1140.

Amin, F., \& Jalilifar, A. (2013). The discourse of war in the Middle East: Analysis of Syria's civil crises in English editorials published in Iran, Turkey, and Saudi Arabia. The Journal of Teaching Language Skills, 5(3), 1-2.

Aouragh, M. (2012). Social media, mediation, and the Arab revolutions. Triple C: Communication, Capitalism \& Critique. Open Access Journal for a Global Sustainable Information Society, 10(2), 518-536.

Aristotle. (2006). On rhetoric: A theory of civic discourse (2nd ed.). (G. A. Kennedy, Trans.) Oxford, England: Oxford University Press. (Original work published 1356)

Asmeret, H. (2013). Ethiopian print media coverage of the Arab uprisings: The case of Addis Zemen, Fetehe, and Reporter (Doctoral dissertation, Addis Ababa University, Addis Ababa, Ethiopia). Retrieved from http:// etd.aau. edu.et/ bitstream/123456789/7492/ 1/Asmeret.pdf

Bardici, M. V. (2012). A discourse analysis of the media representation of social media for social change - The case of the Egyptian revolution and political change (Master's thesis, Malmö University, Malmö, Sweden). Retrieved from http://dspace. mah.se/bitstream/handle/2043/14121/ BardiciVMDP12. pdf? sequence $=2$

Barnsby, R. E. (2012). Social media and the Arab Spring: How Facebook, Twitter, and camera phones changed the Egyptian army's response to revolution (Master's thesis, United States Army Command and General Staff College). Retrieved from http://www.hsdl.org/?view did =72 0811

Baum, M. A., \& Zhukov, Y. M. (2015). Filtering revolution: Reporting bias in international newspaper coverage of the Libyan civil war. Journal of Peace Research, 1-17. doi: $10.1177 / 0022343314554791$

Breuer, I., Napthine, M., \& O'Shea, R. (2008). Persuasive language in media texts. Victoria, Australia: Insight Publications Pty Ltd.

Bruns, A., Highfield, T., \& Burgess, J. (2013). The Arab spring and social media audiences English and Arabic Twitter users and their networks. American Behavioral Scientist, 57(7), 871-898. doi: $10.1177 / 0002764213479374$

Chebib, N. K., \& Sohail, R. M. (2011). The reasons social media contributed to the 2011 Egyptian revolution. International Journal of Business Research and Management (IJBRM), 2, 139-62.

Chokoshvili, D. (2011). The role of the Internet in democratic transition: A case study of the Arab spring (Master's thesis, Central European University, Budapest, Hungary). Retrieved from http://goya.ceu.hu/ search/trole\%20of\%20the\% 20internet

Cottle, S. (2011). Media and the Arab uprisings of 2011: Research notes. Journalism, 12(5), 647-659. doi: $10.1177 / 1464884911410017$

Creech, B. (2014). Disciplines of truth: The Arab spring, American journalistic practice, and the production of public knowledge. Journalism, 1-17. doi: 10.1177/1464884914550971

Culbertson, S. (2016). The fires of spring: A post-Arab spring journey through the turbulent new Middle East- Tunisia, Turkey, Iraq, Jordan, Qatar, Egypt. New York, NY: Macmillan. 
Dağtaş, B. (2013). Constructing the Arab spring: News discourses in Turkish newspapers. Global Media Journal: Canadian Edition, 6(2), 19-33.

Eltantawy, N., \& Wiest, J. B. (2011). Social media in the Egyptian revolution: Reconsidering resource mobilization theory. International Journal of Communication, 5, 1207-1224.

English, K., Sweetser, K. D., \& Ancu, M. (2011). YouTube-ification of political talk: An examination of persuasion appeals in a viral video. American Behavioral Scientist, 55(6), 733-748.

Eskjær, M. F. (2012). Changing revolutions, changing attention? Comparing Danish press coverage of the Arab Spring in Tunisia and Syria. Global Media Journal, 2(1), 1-19.

Fairclough, N. (2006). Language and globalization. New York, NY: Routledge.

Haider, A. S. (2016). A corpus-assisted critical discourse analysis of the Arab uprisings: Evidence from the Libyan case. (Doctoral dissertation, University of Canterbury, Christchurch, New Zealand). Retrieved from https://ir.canterbury.ac.nz/handle/ 10092/13008

Halmari, H., \& Virtanen, T. (Eds.). (2005). Persuasion across genres: A linguistic approach. Amsterdam, The Netherlands: John Benjamins Publishing.

Hamdy, N., \& Gomaa, E. H. (2012). Framing the Egyptian uprising in Arabic language newspapers and social media. Journal of Communication, 62(2), 195-211.doi: 10.1111/j.14602466.2012.01637.x

Hannon, S. (2012). Endorsement editorials: Rhetorical strategies of compelling arguments (Doctoral dissertation, University of Waterloo, Ontario, Canada). Retrieved from https://uwspace. uwaterloo.ca/ bitstream/ handle/ 10012/6680/Hannon_Sheila .pdf? sequence=1

Hassan, S, F. (2015). Social media and the Arab spring (Master's thesis, The State University of New Jersey). Retrieved from https:// rucore. libraries. rutgers. edu/rutgers-lib/46193/

Herrick, J. A. (2013). History and theory of rhetoric: An introduction (5th ed). New York, NY: Routledge.

Higgins, C., \& Walker, R. (2012). Ethos, logos, pathos: Strategies of persuasion in social/environmental reports. Accounting Forum, 36(3), 194-208, doi: 10.1016/j.accfor.2012.02.003.

Identifying Rhetorical Strategies: Logos, Pathos, and Ethos. (2010, October 19). Retrieved from https://www.scribd.com/doc/243580884/rhetorical-strategies-chart

Kadri, A. (Ed.). (2016). Development challenges and solutions after the Arab Spring. Basingstoke, England: Palgrave Macmillan.

Kamau, C., \& Berry, D. (2013). Public policy and media organizations. London, England: Routledge.

Kamel, S. H. (2014). The value of social media in Egypt's uprising and beyond. The Electronic Journal of Information Systems in Developing Countries, 60(5), 1-7.

Lamberti, P. (2013). A critical exploration of argumentation in the texts that third-year development studies students to interpret and construct (Doctoral dissertation, University of Johannesburg, Johannesburg, South Africa). Retrieved from http://hdl.handle. net/10210/8740

Larson, C.U. (1992). Persuasion: Reception and responsibility. Belmont: Wadsworth.

Lotan, et al. (2011). The revolutions were tweeted: Information flows during the 2011 Tunisian and Egyptian revolutions. International Journal of Communication, 5, 1375-1405. 
Lynch, M., Freelon, D., \& Aday, S. (2014). Syria in the Arab Spring: The integration of Syria's conflict with the Arab uprisings, 2011-2013. Research \& Politics, 1(3), 1-7. doi: $10.1177 / 2053168014549091$

Martin, D. W. (2014). Political transition in a post-Arab spring Middle East: A comparative analysis of Tunisia, Egypt, and Yemen (Undergraduate thesis, University of Central Florida, Orlando). Retrieved from http://etd.fcla.edu/CF/CFH0004555/ Martin_Dominic_W_201404_BA.pdf

McKay, S. (2011). Language and the media. In R. Mesthrie (Ed.), The Cambridge Handbook of Sociolinguistics (Cambridge Handbooks in Language and Linguistics, pp. 396-412). Cambridge: Cambridge University Press. doi:10.1017/CBO9780511997068.029

Mureşan, E. C. (2013). Newspaper editorial discourse: The Romanian editorial at times of conflict (Unpublished doctoral dissertation). Babeș-Bolyai University, Romania.

Schueller, R. (2012). Tweet like an Egyptian: The role of social media in the Arab Spring uprisings. (Undergraduate thesis, Ohio University). Retrieved from https://etd.ohiolink.edu/rws_etd/document/get/ouhonors13402940 11/inline

Shabo, M. (2010). Rhetoric, logic, and argumentation: A guide for student writers. Clayton, DE: Prestwick House.

Skinner, J. (2011). Social media and revolution: The Arab spring and the occupy movement as seen through three information studies paradigms. Sprouts: Working Papers on Information Systems, $11(169)$.

Starbird, K., \& Palen, L. (2012). (How) will the revolution be retweeted?: Information diffusion and the 2011 Egyptian uprising. Proceedings of the ACM 2012 Conference on Computer Supported Cooperative Work (pp. 7-16). doi: 10.1145/ 2145204.2145212

Steinberg, S. (1999). Persuasive communication skills: Public speaking. Cape Town, South Africa: Juta Academic.

Ting, S. H. (2018). Ethos, Logos, and Pathos in University Students' Informal Requests. GEMA

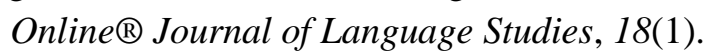

Triana. H. W., Kustati, M., Yusuf, Y. Q., \& Reflinaldi, R. (2021). The representation of women in COVID-19 discourses: The analysis of Sara Mills' critical discourse on media coverage. Journal of Language and Linguistic Studies, 17(Special Issue 1), 553-569.

Tufekci, Z., \& Wilson, C. (2012). Social media and the decision to participate in political protest: Observations from Tahrir Square. Journal of Communication, 62(2), 363-379.

van Dijk, T. A. (1988). News analysis. New Jersey, NJ: Lawrence Erlbaum Associates.

van Dijk, T. A. (1995, December). Opinions and ideologies in editorials. 4th International Symposium of Critical Discourse Analysis, Language, Social Life, and Critical Thought, Athens. Retrieved from http://www. discursos.org/ unpublished\% 20articles/Opinions \%20and\%20ideologies \%20 in\%20 editor ials.htm

Varpio, L. (2018). Using rhetorical appeals to credibility, logic, and emotions to increase your persuasiveness. Perspectives on medical education, 7(3), 207-210.

White, G. B. (2006). Analogical power and Aristotle's model of persuasion. The American Journal of Bioethics, 6(6), 67-68. 
Youssef, A. (2012). A critical analysis on media coverage of the Egyptian revolution: The case of AlAhram, Al-Masry Al-Youm, The Telegraph and The Washington Post (Master's thesis, Örebro University, Örebro, Sweden). Retrieved from http://www.diva portal.org/smash/get/diva2:540808/ FULL TEXT01.pdf

\section{AUTHOR BIODATA}

Dr. Naeem Afzal is affiliated with the Department of English, College of Sciences and Humanities, Prince Sattam bin Abdulaziz University, Saudi Arabia. He holds a Ph.D. in Applied Linguistics from Universiti Utara Malaysia (UUM). His teaching experience expands over 14 years of university teaching. In addition to teaching, he has been responsible for coordinating several duties in the department. He has researched and published papers on topics related to media discourse, discourse analysis, rhetoric, and critical discourse analysis.

Dr. Ismat Jabeen, Assistant Professor at Prince Sattam bin Abdulaziz University, Ph.D. in English from National University of Modern Languages. Her research interests are in the areas of ESP, EFL, ELT, Language and Gender, Critical/Discourse Analysis, and Sociolinguistics. Her major research focuses on exploring the pragmatic use of language and experimenting with a variety of theoretical frameworks and methods in inclassroom contexts. She has extensive teaching and supervising experience in the fields of L2 teaching and learning, language and gender, discourse analysis, and pragmatics.

Dr. Ansa Hameed is currently working as an Assistant Professor at Prince Sattam Bin Abdulaziz University, College of Science and Humanities, Al-Kharj. She has received her Ph.D. degree in Linguistics (English) from NUML, Islamabad in January 2013. Her areas of interest are Ecolinguistics, Sociolinguistics, and Applied Linguistics

Dr. Adnan Rashid Sheikh, Lecturer at Umm Al Qura University, is a Ph.D. in Linguistics from the National University of Modern Languages, Pakistan. His research interests include discourse analysis, cognitive linguistics, gender studies, and Technology Assisted Language Learning (TALL). He has extended teaching experience, of more than two decades, with learners ranging from beginner to post-graduate levels. Besides teaching, he has been part of numerous language translation and integrity projects with entities like Turnitin, Rosetta stone, Mango Languages, etc. 